\title{
Laboratory measurements of natural radioactivity in selected igneous rocks of the Opava Mountains region
}

\author{
Agnieszka Dżaluk ${ }^{1}$, Dariusz Malczewski ${ }^{1}$, Jerzy Żaba ${ }^{2}$, Maria Dziurowicz $^{1}$ \\ ${ }^{1}$ University of Silesia, Faculty of Earth Sciences, Department of Applied Geology; ul. Będzińska 60, 41-200 Sosnowiec, Poland; \\ e-mail:agnieszka.dzaluk@gmail.com,dariusz.malczewski@us.edu.pl,maria.dziurowicz@us.edu.pl \\ ${ }^{2}$ University of Silesia, Faculty of Earth Sciences, Department of Fundamental Geology; \\ ul.Będzińska 60,41-200 Sosnowiec, Poland; e-mail: jerzy.zaba@us.edu.pl
}

(C) 2015 Authors. This is an open access publication, which can be used, distributed and reproduced in any medium according to the Creative Commons CC-BY 4.0 License requiring that the original work has been properly cited.

The paper presents the results of the laboratory gamma-ray measurements of six igneous rocks from the Opava Mountains. The Opava Mountains are located in the Eastern Sudetes and represent their furthest eastern range. They run almost latitudinally along the Polish border with the Czech Republic. The Opava Mountains are mostly situated in the Czech Republic. Only a small fragment between Głuchołazy in the west and Prudnik in the east is situated in Poland (Janeczek et al. 1991). The study area is built of rocks of different ages and lithologies. The Opava Mountains belong to the western part of the Upper Silesia Block, which together with the Brno Block form a structure that is called the Brunovistulicum. The mountains consist of five structural stages: the $\check{Z} u$ lova Massif, the Desna Series, the Vrbno Series, the Andělská-Hora Formation and the Horn-Benešov Formation, which run longitudinally (Żaba et al. 2005). The activities of naturally occurring radionuclides were measured using a portable GX3020 gamma-ray workstation. The system is based on a high-purity germanium (HPGe) detector with a $32 \%$ relative efficiency and energy resolutions of $0.8 \mathrm{keV}$ at $122 \mathrm{keV}$ and $1.7 \mathrm{keV}$ at $1330 \mathrm{keV}$. The activity concentrations of ${ }^{40} \mathrm{~K}$ varied from $519 \mathrm{~Bq} \cdot \mathrm{kg}^{-1}$ (paragneiss, Głuchołazy/Mikulice) to $1559 \mathrm{~Bq} \cdot \mathrm{kg}^{-1}$ (weathered granite, Sławniowice), while those of ${ }^{228} \mathrm{Ac}$ ( ${ }^{232} \mathrm{Th}$ series) from $7.2 \mathrm{~Bq} \cdot \mathrm{kg}^{-1}$ (weathered granite, Sławniowice) to $70.6 \mathrm{~Bq} \cdot \mathrm{kg}^{-1}$ (migmatitic gneiss, Nadziejów). The activities that were associated with ${ }^{226} \mathrm{Ra}\left({ }^{238} \mathrm{U}\right.$ series) ranged from
$5.5 \mathrm{~Bq} \cdot \mathrm{kg}^{-1}$ (weathered granite, Sławniowice) to $52.2 \mathrm{~Bq} \cdot \mathrm{kg}^{-1}$ (gneiss, Kamienna Góra). The measured activity concentrations were compared with the average activity concentration of ${ }^{40} \mathrm{~K},{ }^{228} \mathrm{Ac}$ $\left({ }^{232} \mathrm{Th}\right)$ and ${ }^{226} \mathrm{Ra}\left({ }^{238} \mathrm{U}\right)$ for similar types of rocks reported in the world specialist literature. The average value of the activity concentrations of ${ }^{40} \mathrm{~K}$ for granites and gneisses equals $1000 \mathrm{~Bq} \cdot \mathrm{kg}^{-1}$ (VanSchmus 1995, Eisenbud \& Gesell 1997), which means that the measured value of granite in the Sławniowice quarry is significantly higher than the average one, whereas the activity concentration of paragneiss is almost two times lower than the average value of similar types of rocks. The activity concentrations of ${ }^{228} \mathrm{Ac}\left({ }^{232} \mathrm{Th}\right)$ and ${ }^{226} \mathrm{Ra}$ $\left.{ }^{238} \mathrm{U}\right)$ in measured rocks are comparable to the average values (70 Bq. $\mathrm{kg}^{-1}$ and $40 \mathrm{~Bq} \cdot \mathrm{kg}^{-1}$ respectively (Van Schmus 1995, Eisenbud \& Gesell 1997). Only the activity concentrations of granite in the Sławniowice quarry are considerably lower than the average values for the typical ones because it is strongly weathered. The aim of this paper is to show the first experimental data concerning the activity concentrations of primordial radionuclides in the igneous rocks in the Opava Mountains.

\section{REFERENCES}

Eisenbud M. \& Gesell T., 1997. Natural Radioactivity. [in:] Environmental radioactivity from natural, industrial and military sources, Academic Press, San Diego, CA, 134-200. 
Janeczek J., Kozłowski K. \& Żaba J., 1991. Zbieramy mineraly i skały. Przewodnik po Dolnym Ślasku pod red. naukowa Jerzego Żaby. Wydawnictwa Geologiczne, Warszawa.

Van Schmus W.R., 1995. Natural radioactivity of the Crust and the Mantel. [in:] Ahrens T.J. (eds), Global Earth Physics, American Geophysical Union, Washington, 283-291.
Żaba J., Ciesielczuk J., Malik K. \& Strzyżewska-Konieczna S., 2005. Budowa i ewolucja strukturalna utworów dewońsko-karbońskich Gór Opawskich (strefa śląsko-morawska). [in:] Jureczek J., Buła Z. \& Żaba J. (eds), Geologia i zagadnienia ochrony środowiska w rejonie Górnoślaskim, LXXVI Zjazd Naukowy Polskiego Towarzystwa Geologicznego, Rudy k/Rybnika, Państwowy Instytut Geologiczny, Polskie Towarzystwo Geologiczne, Warszawa, 116-127. 